\title{
Determinants Influencing the Audit Quality: Empirical Evidence from Indonesia
}

\author{
Theresia Prima Risanti ${ }^{1}$, Khoirul Aswar ${ }^{1, *}$, Jumansyah $^{2}$, Wirman $^{3}$ \\ ${ }^{1}$ Department of Accountancy, Faculty of Economics and Business, Universitas Pembangunan Nasional Veteran Jakarta, Indonesia \\ ${ }^{2}$ Department of Accountancy, Faculty of Economics and Business, Universitas Al-Azhar, Indonesia \\ ${ }^{3}$ Department of Accountancy, Faculty of Economics and Business, Universitas Singabangsa Karawang, Indonesia
}

Received July 30, 2021; Revised October 8, 2021; Accepted October 17, 2021

\section{Cite This Paper in the following Citation Styles}

(a): [1] Theresia Prima Risanti, Khoirul Aswar, Jumansyah, Wirman, "Determinants Influencing the Audit Quality: Empirical Evidence from Indonesia," Universal Journal of Accounting and Finance, Vol. 9, No. 6, pp. 1265 - 1272, 2021. DOI: 10.13189/ujaf.2021.090606.

(b): Theresia Prima Risanti, Khoirul Aswar, Jumansyah, Wirman (2021). Determinants Influencing the Audit Quality: Empirical Evidence from Indonesia. Universal Journal of Accounting and Finance, 9(6), 1265 - 1272. DOI: 10.13189/ujaf.2021.090606.

Copyright $\odot 2021$ by authors, all rights reserved. Authors agree that this article remains permanently open access under the terms of the Creative Commons Attribution License 4.0 International License

\begin{abstract}
In producing a reliable audit quality, it requires the quality of the auditors themselves. The Financial and Development Planning Agency (BPKP) is a state institution that is part of the Government Internal Supervisory Apparatus (APIP). This study aims to determine the effect of auditor skepticism, understanding of information systems, auditor education, and audit motivation on audit quality and the effect of time budget pressure in moderating the effect of audit motivation on audit quality. This research was conducted at BPKP DKI Jakarta with a questionnaire instrument and processed using SEM-PLS. The results of this study indicate that auditor skepticism has a significant effect on audit quality. Meanwhile, understanding of information systems, auditor education, and audit motivation doesn't have an effect on audit quality. Time budget pressure also does not moderate the effect of audit motivation on audit quality. This research is expected to be an additional understanding and knowledge about the effect of auditor skepticism, understanding of information systems, auditor education, and audit motivation on audit quality.
\end{abstract}

Keywords Audit Quality, Auditor Skepticism, Understanding of Information Systems, Auditor Education, Audit Motivation

\section{Introduction}

The quality of an audit report is obtained through the process of identifying and reviewing company activities to achieve quality objectives [1]. Audit quality is a possibility where the auditor can find irregularities or fraud in the client's financial reporting system that refers to the applicable standards [2]. Law 15 of 2004 on State Management and Responsibility Audit, Article 9 explains that the Supreme Audit Agency (BPK) can take advantage of the results of the inspection by the government internal supervisory apparatus (APIP) in carrying out performance audits and audits for specific purposes.

APIP is an inspectorate general of ministries, a supervisory unit for non-ministerial government agencies, a province inspectorate, and a regency/city inspectorate, according to Law 23 of 2014 concerning Regional Government. The APIP is made up of the Financial and Development Supervisory Agency (BPKP), the inspectorate general or other entities that effectively carry out the role of internal supervision, provincial inspectorates, and/or district/city inspectors, according to Government Regulation No. 60 of 2008.

BPKP is part of the APIP which is responsible for government tasks in the field of state or regional financial supervision as well as national development. As a board that is directly responsible to for the president and acts as an auditor, the Indonesian government issues a Supervisory Report as the final result of its work. 
In 2013, quoted from detik.com, BPKP admitted to receiving bribes from the ministry of education and culture teacher certification fee. As an auditor, BPKP should supervise and detect fraud itself in an agency. Good performance accountability is needed to create a quality state accountability order. The work of the BPKP, which was originally a report on the results of supervision, turned into a strategic recommendation because there were several problems in implementing the formulation of outcome indicators which caused difficulties in budget proposals and performance management by users of BPKP results. These strategic recommendations are in the form of recommendations to regional heads or agencies to improve governance, risk management, and control over the implementation of program policies.

Many studies have examined the factors that affect the quality of the audit itself. Hikmayah and Aswar [13] states that audit quality is influenced by professional accounting ethics but is not influenced by auditor competence. Meanwhile, professional commitment moderates the effect between auditor integrity and audit quality, but does not moderate the effect between professional commitment and audit quality. In another study conducted by Al-Khaddash [1], it is stated that audit efficiency, audit office reputation, audit fees, organization size, and auditor competence have an influence on audit quality. Meanwhile, auditor independence has no effect on audit quality.

Previous research has revealed the factors that influence audit quality. According to Kusumawati and Syamsuddin [3], auditor skepticism has a considerable impact on audit quality. It is further explained more skeptical the auditors are, the more quality the audit results will produce. Understanding of information systems is the ability of auditors to understand information systems in carrying out audit tasks. According to Oktavianto and Suryandari [4] and Majidah, et al. [5], the aspect of information system comprehension has a substantial impact on audit quality.

One of the things that influences audit quality is auditor education. Auditor education is a formal education that has been taken by auditors and auditor capabilities that have been supported by certification by professional accounting bodies [6]. Ocak [7] found that the level of education can suppress the negative effect of auditor workload density on audit quality. Furthermore, it is also found that auditors who have higher education can optimally cope with client complexity. Chu et al [6] found that auditors from accounting education have a better ability to detect fraud or manipulation. However, Hambrick and Manson [8] did not find any effect of auditor education on the results of audit opinions.

The third component is audit motivation, which has a considerable impact on audit quality. Audit motivation is the extent to which auditors process the impulse to produce quality audits to run operations and continue their business $[9,10,11]$. Lastly, the moderating variable in this study is time budget pressure. This variable explains the conditions in which an auditor is required to perform efficiency with respect to the time budget that has been prepared. Halim et al. [12] use this variable and explain that the use of a long audit time budget will make the auditor not motivated to work optimally. This study is a development of the limitations of previous studies that have been carried out by Hikmayah and Aswar [13], Al-qatamin [14], Hambrick and Manson [8] using the variables that are suggested by each study.

Based on the above explanation, the purpose of this study is to see how auditor skepticism, knowledge of information systems, auditor education, and audit motivation affect audit quality. This study also aims to determine the effect of time budget pressure in moderating audit motivation on audit quality. The next section is literature review, which discusses theoretical perspective and hypotheses development.

\section{Literature Review and Hypothesis Development}

\subsection{Theoretical Perspective}

Attribution theory is a theory that describes individual behavior. This idea demonstrates how a person decides the reason for his actions. This theory describes how the impact caused by internal factors or external factors can affect the behavior of a person [2]. This theory is used to explain the effect of understanding on information systems, skepticism, auditor education and audit motivation on audit quality.

Inverted $\mathrm{U}$ theory is used to explain the moderating variable and time budget pressure. This theory explains the relationship between pressure and work results. If someone gets the right pressure, it will produce optimal work results. However, if the pressure applied is too weak or too strong, it reduces a person's performance [4].

\subsection{Audit Quality}

Audit quality is the work of auditors in the form of reliable work in accordance with applicable standards. Audit quality is also defined as the characteristics and description of the audit in accordance with standards that reflect the duties and responsibilities of the professional auditor [15]. Audit quality is also a tool used by management to evaluate and confirm activities related to quality, independence, and systematic analysis related to the compatibility between strategic planning and the results achieved by the company [3]. In line with Kusumawati and Syamsuddin [3], Ilat [2] stated that audit quality is the possibility that the auditor may encounter irregularities or fraud in the auditee's financial reporting system that refers to applicable standards. 
Financial reports that have high quality are used by agencies to be held accountable to the public for the use of state money. To ensure that the financial statements are of high quality, it is necessary to carry out an audit in accordance with the standards [4]. Reliable and reliable audit quality is a work demand accepted by auditors [10]. The reason is that users of financial statements in Indonesia expect that budget managers can account for the existing budget for the benefit of the state. Therefore, with the existence of auditors, users of financial statements can ensure that budget management has effectively executed.

\subsection{Auditor Skepticism}

Auditor skepticism is the ethics held by the auditor when carrying out the audit process. Auditors who have high commitment will maintain their skepticism to produce better audit quality [3]. According to Setiyawati et al. [16], the attitude of the auditor who always doubts, questions, is critical of the existing audit evidence, and makes audit decisions based on his audit experience is the definition of auditor skepticism.

Determining the level of skepticism is very important because skepticism can affect the effectiveness and efficiency of the audit process [17]. Auditor who uses skepticism in their work will not easily believe or feel confident about what is happening [16]. Professional skepticism of government auditors is one of the crucial elements in obtaining quality government financial reports Supervision by APIP can be carried out properly and produce a quality audit if it is supported by the auditor's skepticism [17]. Therefore, one of the factors that can affect audit quality is auditor skepticism.

\subsection{Understanding of Information Systems}

Understanding information systems is the ability of an auditor to understand the information system as a tool related to the institution being examined and the software used to examine it $[5,4]$. Understanding information systems will make it easier for auditors to optimize audit technology, so they can optimize audit quality accurately, quickly, and reliably.

An understanding of information systems will show how far the company's information systems are related to each other between departments [4]. The quality of the audit report can be influenced by the behavior of the internal auditor's factors, namely knowledge of information systems.

\subsection{Auditor Education}

Auditor education is a formal education that has been taken by auditors and the ability of auditors is supported by certification by professional accounting bodies [6]. The education level of auditors is very important because in carrying out their duties, education can support competence [18]. Auditors with higher education can solve auditee complexity better [7]. Formal education will make a person moral and educated, and easier to learn things related to work.

The audit performance carried out by APIP must be supported by certain criteria for the auditor to suit the needs and situations and conditions experienced by APIP. In order to produce good audit quality and gain full trust from the public, good auditor performance is needed. Qualifications from auditor education can also streamline time and overcome problems that arise due to the lack of time needed to carry out audits [7]. So, it can be explained that audit quality can be influenced by auditor education factors.

\subsection{Audit Motivation}

Motivation is a process to determine the intensity, direction, and desire of a person to take an action to achieve his goals [9]. Positive motivation is process of influencing someone to do what we want in achieving a goal [10]. Motivation can be a strength, complex condition, and readiness of auditor to continue towards a goal [19]. Audit motivation is very influential in the results given [19]. Audit motivation arises because an auditor has confidence that he can complete the audit [9]. Thus, audit motivation, a behavior carried out by auditors, has an important influence on audit quality.

\subsection{Time Budget Pressure}

Time budget pressure is a condition where an auditor is required to streamline the time budget that has been prepared. Time budget pressure is caused by the costs that must be incurred in the audit process [20]. An auditor faces time pressure when he has to complete the audit in accordance with the time determined by the accounting firm [14].

Time budget pressure can be a pressure for employees if the company's evaluation is based on achievements in the time budget, not on the quality of audit work [21]. There is a relationship between audit quality and time budget pressure. When the time budget is an indicator of achievement, and difficult to achieve, this will be a pressure that can cause stress. Thus, the resulting audit quality will also decrease [20]. Due to the relationship between time budget pressure and audit quality, time budget pressure was chosen to be the variable that moderates audit motivation in influencing audit quality.

\section{Hypotheses Development}

The hypotheses in this study are based on factors that are believed to have an impact on the quality of internal auditing in the government sector, so it can be stated as follows.

\subsection{Auditor Skepticism}

Supervision by APIP can be carried out well and 
produce quality audits if it is supported by the auditor's skepticism [17]. Auditor skepticism has a considerable impact on audit quality, according to Setiyawati et al. [16] and Kusumawati and Syamsuddin [3]. Supervision by APIP can be carried out well and produce quality audits if it is supported by the auditor's skepticism because the more skeptical the auditors, the better the resulting audit quality.

H1: The level of skepticism significantly affects the audit quality.

\subsection{The Understanding of Information System}

An understanding of information systems makes it easier for auditors to optimize audit technology which leads to optimizing audit quality accurately, quickly and reliably. To get optimal audit quality, one of the factors is the understanding of information systems [4].

$\mathrm{H} 2$ : Understanding of information systems significantly affects the audit quality.

\subsection{Auditor Education}

The audit performance conducted by APIP must be supported by auditors with certain criteria to suit the needs of APIP and the situations and conditions experienced by APIP. Auditor education level is very important because in carrying out their duties, education can support competence [18]. Auditors with higher education are able to solve the complexity of the auditee better [7]. Auditor education has a considerable impact on audit quality [15].

H3: Auditor education significantly affects the audit quality.

\subsection{Audit Motivation}

One of the beliefs that the auditor must have in order to do his duties is audit motivation [9]. According to Wardana et al. [19], Audit motivation is very influential on the results given. Kuntari et al. [11] and Aswar et al. [22] discovered that audit motivation has a big impact on audit quality.

H4: Audit motivation significantly affects the audit quality.

\subsection{Time Budget Pressure}

According to Amalia et al [23], time budget constraints can influence the relationship between audit quality and independence. Time budget pressure can be a pressure for employees. This happens when evaluation of the company is based on the achievement of the time budget, not on the quality of the audit work [21]. Time budget pressure has a considerable effect on premature sign-off [14].

H5: Time budget pressure moderates the effect of audit motivation on audit quality.

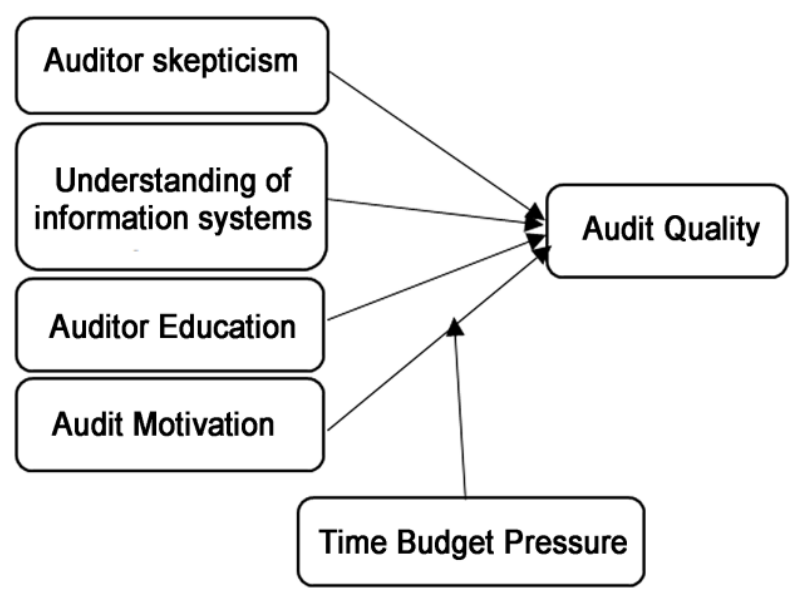

Figure 1. Conceptual Model

\section{Methodology}

The sample consist 87 auditors in BPKP. The reason for taking BPKP DKI Jakarta members as samples is to present the quality of audit that presented by government section. DKI Jakarta as capital city of Indonesia, chosen as place to sampling. The sample of this research is auditors at BPKP DKI Jakarta who have attended the functional auditor position (JFA) with a minimum experience of 2 years as presented in Table 1. The sample selection is based on census sampling.

Table 1. Respondent Demography

\begin{tabular}{|c|c|c|c|}
\hline Characteristics & Information & Frequency & Percentage \\
\hline Gender & Men & 22 & $44 \%$ \\
\hline \multirow{6}{*}{ Last education } & Woman & 28 & $56 \%$ \\
\hline & Diploma 3 (D3) & 6 & $12 \%$ \\
\hline & Diploma 4 (D4) & 10 & $20 \%$ \\
\hline & $\begin{array}{c}\text { Bachelor degree } \\
\text { (S1) }\end{array}$ & 24 & $48 \%$ \\
\hline & Postgraduate (S2) & 9 & $18 \%$ \\
\hline & Doctoral (S3) & 1 & $2 \%$ \\
\hline \multirow[t]{8}{*}{ Position } & $\begin{array}{c}\text { Associate Expert } \\
\text { Auditor }\end{array}$ & 1 & $2 \%$ \\
\hline & $\begin{array}{c}\text { Young Expert } \\
\text { Auditor }\end{array}$ & 1 & $2 \%$ \\
\hline & $\begin{array}{c}\text { Intermediate } \\
\text { Auditor }\end{array}$ & 12 & $24 \%$ \\
\hline & Young Auditor & 14 & $28 \%$ \\
\hline & $\begin{array}{c}\text { Supervisory } \\
\text { Auditor }\end{array}$ & 5 & $10 \%$ \\
\hline & First Auditor & 2 & $4 \%$ \\
\hline & $\begin{array}{l}\text { Supervisory } \\
\text { Coordinator }\end{array}$ & 4 & $8 \%$ \\
\hline & $\begin{array}{c}\text { Didn't mention } \\
\text { position }\end{array}$ & 9 & $18 \%$ \\
\hline \multirow[t]{4}{*}{ Long Served } & 2-5 years & 7 & $14 \%$ \\
\hline & $6-10$ years & 10 & $20 \%$ \\
\hline & $11-15$ years & 7 & $14 \%$ \\
\hline & $>15$ years & 17 & $34 \%$ \\
\hline
\end{tabular}

Total respondent of the sample is 50 persons. The questionnaire was delivered to all sample and processed with SEM-PLS technique. The measurement of the variables is presented in Table 2: 
Table 2. Variable Measurement

\begin{tabular}{|c|c|c|}
\hline No. & Variable & Indicator \\
\hline 1. & Audit quality [4] & $\begin{array}{l}\text { Propose audit findings carefully and objectively } \\
\text { Reveal the auditee's mistakes } \\
\text { Carry out audits on time } \\
\text { Guided by SPAP } \\
\text { Be careful in making decisions } \\
\begin{array}{c}\text { Provide advice that is appropriate to the cause of the error, and provide advice on the audit } \\
\text { report that is clear and understandable to the auditee }\end{array}\end{array}$ \\
\hline 2. & Auditor skepticism [17] & $\begin{array}{c}\text { Think critically } \\
\text { Don't rush into making decisions } \\
\text { Develops his knowledge } \\
\text { Understand yourself } \\
\text { Confidence } \\
\text { Take responsibility for your own destiny }\end{array}$ \\
\hline 3. & $\begin{array}{l}\text { Understanding of } \\
\text { information systems [4] }\end{array}$ & $\begin{array}{l}\text { Auditors have an understanding of the information system } \\
\text { The auditor has an understanding of the client's information system } \\
\text { Auditors have the benefit of understanding the information system }\end{array}$ \\
\hline 4. & Auditor education [15] & $\begin{array}{l}\text { Formal education in accounting, especially auditing assignments, following adequate } \\
\text { training, and following continuing professional education. } \\
\text { Mentally independent } \\
\text { Professional expertise }\end{array}$ \\
\hline 5. & Audit motivation [11] & $\begin{array}{c}\text { Policy and quality of service } \\
\text { Self-evaluation } \\
\text { Consistency of audit results } \\
\text { Critical in carrying out the audit task }\end{array}$ \\
\hline 6. & $\begin{array}{l}\text { Time Budget Pressure } \\
\text { [22] }\end{array}$ & $\begin{array}{c}\text { The auditor has a time budget to control the total amount of time for the audit work as a whole } \\
\text { The auditor has a deadline related to the time } \\
\text { budget to complete the work according to the deadline }\end{array}$ \\
\hline
\end{tabular}

\section{Result}

\subsection{Descriptive Statistics}

This questionnaire was distributed to 87 samples online with 50 questionnaires successfully filled out. The response rate in this study was $57.5 \%$ and the questionnaires that were not successfully filled out were $42.5 \%$.

Descriptive statistics are a step to understand a sample of research. Descriptive statistics are used to categorize samples and check whether there are irrelevant statistical assumptions [24]. From this stage, we can process the details of the data to enter the next stage [25]. These statistical measures, for the most part, use mean and standard deviation to describe the research data.

According to Sekaran and Bougie [25], Mean is a measure of central tendency that presents a data description without filling it with data sets. Meanwhile, standard deviation is another measure in describing a measure of the spread of data and the ratio of data scales, where the standard deviation provides an index of the distribution of distribution or data variability. Statistical descriptive are described in Table 3.

In the results outlined in the table above, the standard deviation of each variable is lower than mean value. These results indicate that the smaller the standard deviation represents a fairly high homogeneity of data and illustrates the average data that reflects the real data.
Table 3. Descriptive Statistic

\begin{tabular}{|c|c|c|c|c|}
\hline No & Variable & $\begin{array}{c}\text { No. } \\
\text { Questions }\end{array}$ & Mean & $\begin{array}{c}\text { Standard } \\
\text { Deviation }\end{array}$ \\
\hline 1 & Audit Quality (AQ) & 12 & 4.65 & 0.58 \\
\hline 2 & $\begin{array}{c}\text { Auditor Skepticism } \\
\text { (AS) }\end{array}$ & 6 & 4.44 & 0.54 \\
\hline 3 & $\begin{array}{c}\text { Understanding of } \\
\text { Information Systems } \\
\text { (UIS) }\end{array}$ & 5 & 3.72 & 0.94 \\
\hline 4 & $\begin{array}{c}\text { Auditor Education } \\
\text { (E) }\end{array}$ & 4 & 4.20 & 0.75 \\
\hline 5 & $\begin{array}{c}\text { Audit Motivation } \\
\text { (AM) }\end{array}$ & 4 & 3.99 & 0.70 \\
\hline 6 & $\begin{array}{c}\text { Time Budget } \\
\text { Pressure (TBP) }\end{array}$ & 8 & 2.49 & 1.05 \\
\hline
\end{tabular}

\subsection{Structure Equation Model Result}

This study uses Structure Equation Modeling (SEM) for data processing. Partial Least Square (PLS) is an SEM equation model which is a re-approach where this technique maximizes the explanation of the problems studied [26]. PLS is a data analysis technique that can process data both in very large and small quantities and can be used in non-normal data.

The following are the results of smartPLS 3.0 related to the composite reliability, Cronbach alpha and validity values for each variable: 
Table 4. Convergent Validity and Reliability

\begin{tabular}{|c|c|c|c|}
\hline & $\begin{array}{c}\text { Composite } \\
\text { Reliability }\end{array}$ & $\begin{array}{c}\text { Cronbach's } \\
\text { Alpha }\end{array}$ & AVE \\
\hline AQ & 0.874 & 0.831 & 0.500 \\
\hline AS & 0.867 & 0.857 & 0.580 \\
\hline UIS & 0.886 & 0.836 & 0.613 \\
\hline E & 0.81 & 0.689 & 0.593 \\
\hline AM & 0.805 & 0.645 & 0.589 \\
\hline TBP & 0.819 & 0.803 & 0.628 \\
\hline
\end{tabular}

Table 4 shows that all variables show a composite reliability value $>0.70$ which means, all statements in this study are considered to have met the criteria. The lowest composite reliability value in this test is audit motivation, which is 0.805 . Furthermore, all variables show the value of Cronbach's alpha $>0.60$ where the highest Cronbach's alpha is 0.857 , namely auditor skepticism. This shows that all statements in this study have good reliability in their respective constructs. The AVE value which is above 0.50 illustrates that the variables in this study can be said to be valid.

Furthermore, the Inner model is evaluated by looking at the percentage of variance explained by looking at the $\mathrm{R}$-Square, Q-Square test. The R-square test was carried out on the dependent variable, namely audit quality. Here are the results of the R-square test:

Table 5. R-Square

\begin{tabular}{ccc}
\hline & R-Square & Adjusted R-Square \\
\hline Audit quality & 0.502 & 0.428 \\
\hline
\end{tabular}

The Q-Square test is used to measure the quality of the observed values obtained from the model and parameter estimates. Q-square value $>0$ indicates the model has predictive relevance while $\mathrm{Q}$-square value 0 indicates the model lacks predictive relevance [26]. Q-Square calculation results can be calculated using the formula:

$$
\begin{gathered}
\mathrm{Q}^{2}=1-\left(1-\mathrm{R}_{1}{ }^{2}\right)\left(1-\mathrm{R}_{2}{ }^{2}\right) \ldots\left(1-\mathrm{R}_{\mathrm{p}}{ }^{2}\right) \\
\mathrm{Q}^{2}=1-\left(1-\mathrm{R}_{1}{ }^{2}\right) \\
\mathrm{Q}^{2}=1-(1-0.428) \\
=0.502
\end{gathered}
$$

The Q-Square of this study is 0.502 , where this quantity is in the range $0<\mathrm{Q} 2$, so it can be concluded that $\mathrm{Q} 2$ of this study has predictive relevance.

\subsection{Hypothesis Testing}

Testing the hypothesis of this study using t-value and p-value to see the relationship between the independent and dependent variable. Then, influence time budget pressure (TBP) in moderating the relationship between audit motivation and audit quality. It is known that the t-table in this study is 2.014 which is obtained through $\mathrm{df}$ $=\mathrm{n}-\mathrm{k}$ where $\mathrm{df}=50-5$ with a $5 \%$ confidence degree.
Table 6. PLS Algorithm and Bootstrapping

\begin{tabular}{|c|c|c|c|}
\hline & Original sample & T-Value & P-Value \\
\hline AS -> AQ & 0.41 & 2.36 & 0.019 \\
\hline UIS-> AQ & 0.336 & 1,672 & 0.095 \\
\hline E -> AQ & 0.258 & 1,521 & 0.129 \\
\hline AM-> AQ & -0.17 & 0.776 & 0.438 \\
\hline AM -> TBP -> AQ & -0.09 & 0.652 & 0.514 \\
\hline
\end{tabular}

Meanwhile, as we can see from the Table 4, this study's hypothesis was examined using a t-statistical test to determine the level of significance between the variables of auditor skepticism and audit quality. Auditor skepticism, as can be seen, has a considerable impact on audit quality. The test results show that tcount $>$ ttable is $2.360>2.014$ and the significance value shows a value of $0.012<0.050$. Meanwhile, other hypothesis testing shows different results. The findings of this study are consistent with those of Setiyawati et al. [16] and Kusumawati and Syamsuddin [3]. The results of this research are also in line with attribution theory where a person's attitude will affect his/her behavior. In this case, the auditor's skepticism as one of the attitudes held by the auditor affects his behavior in acting, so that it can affect the work of the auditor.

Understanding information systems has no significant impact on audit quality. The results of this study indicate that tcount $<$ ttable is $1.672<2.014$ and a significance value shows $0.080>0.050$. Thus, $\mathrm{H} 2$ is rejected. A new finding indicates that understanding the information system is not the most important thing in carrying out the audit task so that it does not affect the quality of the resulting audit. Judging from the results of the mean understanding of information systems is 3.7 while the standard deviation of this variable is 0.94 . These results illustrate that the standard deviation is still quite large so that the diversity of respondents' answers tends to underrepresent the actual conditions. This study also does not support attribution theory which states that understanding of information systems is one of the internal attributions that can affect a person's behavior.

Auditor education has no significant effect on audit quality. The $\mathrm{T}$ test results show tcount $<$ ttable, namely $1.521<2.014$ and the significance value shows $0.116>$ 0.050 . So that $\mathrm{H} 3$ is rejected. Judging from the results of descriptive statistics, the mean of the auditor education variable is 4.20 with a standard deviation of 0.75 . The standard deviation which tends to be low illustrates the homogeneity of the respondents' answers and the average represents the real data. Another reason for the rejection of this hypothesis is the measurement of professional expertise, 18 out of a total of 50 respondents or about $36 \%$ of the respondents stated that they do not need it knowledge obtained from courses and training, especially in the field of auditing, except from formal education.

The quality of an audit is unaffected by the motivation 
of the auditor. The test results show that tcount $<$ ttable is $0.776<2.014$ and a significance value shows a value of $0.435>0.050$. Then $\mathrm{H} 4$ is rejected. These findings are consistent with those of Zahmatkesh and Rezazadeh [27], Furiady and Kurnia [10], and Wardana et al [19]. The rejection of this hypothesis also indicates that the results of this study do not support the attribution theory. When viewed from the indicator "critical in carrying out an audit task," as many as 27 respondents or $54 \%$ of the respondents stated that they were neutral on these indicators. This is also supported by the standard deviation of audit motivation of 0.70 with a mean of 3.99 . The mean describes the characteristics of the research data while the standard deviation represents the diversity of the respondent's responses.

The relationship between audit motivation and audit quality cannot be moderated by time budget pressure. H5 was rejected as a result of this. Judging from the results of the mean and standard deviation, the mean time budget pressure is 2.49 and the standard deviation is 1.05 . This illustrates that the standard deviation which tends to be large does not provide homogeneous data. The mean of 2.49 shows that the variety of answers to the questionnaire given tends to be in the neutral range, disagree, and strongly disagree. This study supports the findings of Majidah et al. [5] Aswar et al [22], who found that time budget pressure has no substantial impact on audit quality. The relationship between audit motivation and audit quality cannot be strengthened or weakened by time budget pressure. In the last questionnaire statement, "when I experience time budget pressure, I tend to have difficulty completing complex audit tasks," 27 respondents or about $54 \%$ of the respondents stated that they were neutral on this statement. So, time budget pressure is not the main thing in strengthening or weakening audit motivation to produce quality audit results. This study contradicts the inverted $U$ theory which states that a person's performance results are influenced by the amount of pressure received.

\section{Conclusion}

The purpose of this study was to see how auditor skepticism, information system understanding, auditor education, and audit motivation affected audit quality. As well as to determine the effect of time budget pressure in moderating audit motivation on audit quality. The results of this study indicate that auditor skepticism has a significant effect on audit quality. Therefore, the higher the auditor's skepticism, the higher the quality of the audit produced. Meanwhile, understanding of information systems, auditor education, and audit motivation do not have an effect on audit quality. This shows that the higher the auditor's understanding of the information system, the lower the audit quality will be. The higher the auditor's education, the lower the audit quality will be. If the audit motivation is high, the resulting audit quality will be low. The influence of audit motivation on audit quality is not moderated by time budget pressure. This shows that time budget pressure in audit motivation does not affect the quality of the resulting audit.

The limitation in this study is that the number of respondents in this study is 50 respondents, while the total sample given by the questionnaire is 87 . There are $42.5 \%$ of the samples who did not fill out the questionnaire because this research was conducted at the close of the year so that the samples were in a busy life which was difficult to be contested.

\section{REFERENCES}

[1] Al-Khaddash, H., Nawas, R. Al, \& Ramadan, A. "Factors affecting the quality of Auditing: The Case of Jordanian Commercial Banks", International Journal of Business and Social Science, vol.4, no.11, pp: 206-222, 2016.

[2] Ilat, V., Saerang, DPE, \& Wokas, HRN. "Determinant's Audit Quality of Local Government in Indonesia", Research Journal of Finance and Accounting, vol.7, no.2, pp: 213-224, 2016.

[3] Kusumawati, A., \& Syamsuddin, S. "The effect of auditor quality to professional skepticism and its relationship to audit quality", International Journal of Law and Management, vol.31, no.4, pp: 949-980, 2018. https://doi.org/10.1108/IJLMA-03-2017-0062

[4] Oktavianto, DD, \& Suryandari, D. "The Factors Affecting the Audit Quality with the Understanding on Information Systems as the Moderating Variable", Accounting Analysis Journal, vol.7, no.3, pp: 168-175, 2018. https://doi.org/10. 15294/aaj.v7i3.21008

[5] Majidah, Isynuwardhana, D., \& Anna, YD. “Audit Quality: Time Budget Pressure, Dysfunctional Auditor Behavior and The Understanding of Information Technology as Moderator", The 7 Th Smart Collaboration for Business in Technology and Information Industries, 2, pp: 295-300, 2016.

[6] Chu, J., Florou, A., \& Pope, PF. "Does Accounting Education add Value in Auditing? Evidence from the UK", Journal of Chemical Information and Modeling. vol.53, no.9, 2017.

[7] Ocak, M. "The impact of auditor education level on the relationship between auditor busyness and audit quality in Turkey", Cogent Business and Management, vol.5, no.1, pp: 1-20, 2018. https://doi.org/10.1080/23311975.2018.15175 88

[8] Hambrick, D., \& Mason, P. "Upper Echelons: The Organization as a Reflection of Its Top Managers", The Academy of Management Review, vol.9, no,2, pp:193-206, 1984. https;//doi.org/10.2307/258434

[9] Asmara, RY. "Quality of Audit: Survey on the External Auditor Registered", European Journal of Accounting, 
Auditing and Finance Research, vol.4, no.1, pp: 43-76, 2016.

[10] Furiady, O., \& Kurnia, R. "The Effect of Work Experiences, Competency, Motivation, Accountability and Objectivity towards Audit Quality", Procedia - Social and Behavioral Sciences, Vol.211, pp:328-335, 2015.https://doi.org/10.10 16/j.sbspro.2015.11.042

[11] Kuntari, Y., Chariri, A., \& Nurdhiana, N. "The Effect of Auditor Ethics, Auditor Experience, Audit Fees and Auditor Motivation on Audit Quality", Sriwijaya International Journal of Dynamic Economics and Business, vol.1, no.2, pp: 203-218, 2017. https://doi.org/10.29259/sij deb.v1i2.17

[12] Halim, A., Sutrisno, T., \& Achsin, M. "Effect of Competence and Auditor Independence on Audit Quality with Audit Time Budget and Professional Commitment as a Moderation Variable", International Journal of Business and Management Invention, vol.3, no,6, pp: 64-74, 2014.

[13] Hikmayah, N., Aswar, K. "The Impact of Factors on the Audit Quality in Indonesia: The Moderating Effect of Professional Commitments, International", Journal of Academic Research in Accounting, Finance and Management Sciences, vol.9, no.4, pp: 285-293, 2019.

[14] Al-qatamin, KI. "The Impact of Time Pressure on the Audit Quality: A Case Study in Jordan The Impact of Time Pressure on the Audit Quality: A Case Study in Jordan", IOSR Journal of Business and Management, vol.22, no.1, pp: 8-16, 2020. https://doi.org/10.9790/487X-2201050816.

[15] Ramlah, S., Sappewali, B., Dwiyanti, E., \& Pontoh, GT. "The Effect of Honesty (Integrity) Auditors, Genders and Education Levels on Audit Quality", International Conference on Accounting, Management and Economics, 2019. https://doi.org/10.4108/eai.25-10-2019.2295359

[16] Setiyawati, H., Iskandar, D., \& Putri, GA. "The factors that affect the audit quality", EPRA International Journal Of Economic and Business Review, vol.8, no.1, Page: 48-53, 2020.

[17] Husnianto, Pituringsih, E., \& Animah. "Influences of the auditor's professional skeptics, competence, and ethical judgment", International Conference and Call for Papers, pp: 1391-1410, 2017.

[18] Sari, D.K.P, \& Hariadi, B. "The Influence of Educational
Background and Ethics on Audit Quality: A Case Study in PWC, EY, Deloitte, and KPMG", Journal of Chemical Information and Modeling, vol.53, no.9, pp: 1689-1699, 2019.

[19] Wardana, IMW, Sapta, IKS, \& Landra, IN. "Competency, independence, motivation, auditor objectives, audit quality, leading policy at Badung Regency Inspectorate", International Journal of Sustainability, Education, and Global Creative Economic, vol.2, no.3, pp: 330-338, 2019.

[20] Pasamba, E. M., \& Sutrisno, T. "The effect of independence and auditor professionalism on audit quality with time budget pressure as a moderating variable", International Journal of Business, Economics and Law, vol.18, no.5, pp: 347-356, 2019.

[21] Mcnamara, S. M., \& Liyanarachchi, G. A. "Time budget pressure and auditor dysfunctional behaviour within an occupational stress model", Accountancy Business and the Public Interest, vol.7, no.1, pp: 1-43, 2008.

[22] Aswar, K., Akbar, F, G., Miguna, M., \& Hariyani, E. " Determinants of Audit Quality: Role of Time Budget Pressure", Problem and Perspective in Management, vol.19, No.2, pp.308-319, 2021. https://doi.org/10.21511/ppm.19( 2). 2021.25

[23] Amalia, FA, Sutrisno, S., \& Baridwan, Z. "Audit Quality: Does Time Pressure Influence Independence and Audit Procedure Compliance of Auditor?", Journal of Accounting and Investment, vol.20, no.1, 2019. https://doi.org/10.1819 6/jai.2001112.

[24] Pallant, J. "SPSS Survival Manual: A Step by Step Guide to Data Analysis using SPSS for Windows (Version 12)", 2005.

[25] Sekaran, U., \& Bougie, R. "Research methods for business: A skill-building approach", 2016.

[26] Hair, J. F., Sarstedt, M., Hopkins, L., \& Kuppelwieser, V. G. (2014). Partial least squares structural equation modeling (PLS-SEM): An emerging tool in business research. European Business Review, 26(2), 106-121. https://doi.org/10.1108/EBR-10-2013-0128

[27] Zahmatkesh, S., \& Rezazadeh, J. "The effect of auditor features on audit quality", TÉKHNE - Review of Applied Management Studies, vol.15, no.2, pp:79-87, 2019. https://doi.org/10.1016/j.tekhne.2017.09.003 